\title{
Composition of Hydrocarbons in Oils from Central Part of the Eastern Siberia
}

\author{
Alexandra R. Akhmedova*a, \\ Olga V. Serebrennikova ${ }^{\mathrm{b}, \mathrm{c}}$ and Olga V. Shiganova ${ }^{\mathrm{a}}$ \\ ${ }^{a}$ Siberian Research Institute of Geology \\ Geophysics and Mineral Resources \\ 67 Krasny prospect, Novosibirsk, 630091, Russia \\ ${ }^{b}$ Institute of Petroleum Chemistry RAS SB \\ 4 Akademichesky, Tomsk, 634055, Russia \\ ${ }^{c}$ National Research Tomsk Polytechnic University \\ 30 Lenin, Tomsk, 634050, Russia
}

Received 13.10.2017, received in revised form 09.02.2018, accepted 11.04.2018

The composition of saturated and aromatic hydrocarbons (HC) of oils in the Central part of Eastern Siberia was studied by gas-chromatography and chromato-mass-spectrometry. It is shown that the source organic matter of all studied oils were formed in marine conditions, and the level of its thermal conversion maximum in oils from Riphean deposits of the Baikit petroleum-bearing region (PBR). According to the thermal maturity of organic matter, as well as by the nature of the molecular mass distribution of saturated and aromatic HC containing long alkyl chain substituent, Riphean oil form a independent group. The second group consists of oils from Vendian-Cambrian sediments of the Katanga, and Nepa-Botuobian PBR.

Keywords: oil, East Siberia, Siberian Platform, chromato-mass-spectrometry, alkanes, drimanes, steranes, tri-, tetra- and pentacyclic terpanes, alkylbenzenes, naphthalenes, phenanthrenes.

Citation: Akhmedova A.R., Serebrennikova O.V., Shiganova O.V. Composition of hydrocarbons in oils from central part of the Eastern Siberia, J. Sib. Fed. Univ. Chem., 2018, 11(2), 230-248. DOI: 10.17516/1998-2836-0071.

(C) Siberian Federal University. All rights reserved

* Corresponding author E-mail address: ahmedova-sniiggims@yandex.ru 


\title{
Состав углеводородов нефтей
}

\section{центральной части Восточной Сибири}

\author{
А.Р. Ахмедова ${ }^{a}$, О.В. Серебренникова ${ }^{6, \mathrm{~g}}$, О.В. Шиганова ${ }^{\mathrm{a}}$ \\ ${ }^{a}$ Сибирский научно-исследовательский институт геологии, \\ геофизики и минерального сырья \\ Россия, 630091, Новосибирск, Красный проспект, 67 \\ ${ }^{6}$ Институт химии нефти СО РАН \\ Россия, 634055, Томск, пр. Академический, 4 \\ ${ }^{8}$ Наииональный исследовательский \\ Томский политехнический университет \\ Россия, 634050, пр. Ленина, 30
}

Состав насыщенных и ароматических углеводородов (УВ) нефтей центральной части Восточной Сибири был изучен методом газожидкостной хроматографии и хромато-массспектрометрии. Показано, что исходное органическое вещество всех исследованных нефтей формировалось в морских условиях, а степень его термического преобразования максимальна в нефтях из рифейских отложений Байкитской НГО. По термической зрелости органического вещества, а также по характеру молекулярно-массового распределения насыщенных и ароматических УВ, содержащих длинный алкильный заместитель, рифейские нефти образуют отдельную группу. Вторую группу составляют нефти венд-кембрийских отложений Катангской и Непско-Ботуобинской НГО.

Ключевые слова: нефть, Восточная Сибирь, Сибирская платформа, хромато-массспектрометрия, алканы, дриманы, стераны, три-, тетра- и пентациклические терпаны, алкилбензолы, нафталины, фенантрены.

\section{Введение}

На территории центральной части Восточной Сибири в отложениях верхнего протерозоя (венд, рифей) и нижнего кембрия открыто свыше 40 месторождений углеводородов, многие из которых (Юрубчено-Тохомское, Собинское, Верхнечонское, Талаканское и др.) по запасам относятся к категориям «гигантские» и «крупные». Их геологическая характеристика приведена в работе [1]. Нефти из этих отложений являются древнейшими на Земле, возраст нефтесодержащих толщ варьирует от 509 до 1100 млн лет [2].

Изучению состава насыщенных УВ, таких как нормальные и изопреноидные алканы, стераны и терпаны, нефтей верхнего протерозоя (венд, рифей) и нижнего кембрия центральной части Восточной Сибири, посвящен ряд работ [3-7], в которых установлены специфические черты, отличающие их от нефтей фанерозоя. Однако до сих пор остается дискуссионным вопрос о происхождении этих нефтей. Нет единого мнения об их классификации и выделении генетически единых групп, характеризующихся общностью состава и свойств. Авторы работ 
$[4,5]$ на основе анализа некоторых физико-химических характеристик и состава насыщенных углеводородов подразделили «древние» нефти Центральной части Восточной Сибири на два семейства. К первому семейству ими отнесены малосернистые рифейские нефти Байкитской антеклизы, отличающиеся от второго семейства (нефти венд-нижнекембрийских отложений Непско-Ботуобинской антеклизы и Катангской седловины) обогащенностью высокомолекулярными УВ, пониженным содержанием ациклических изопреноидов и разветвленных по центральному атому цепи 12- и 13-монометилалканов (ММА). У них более низкое по сравнению с нефтями второго семейства содержание стеранов и понижена доля среди них холестанов, менее выражено преобладание гопанов $\mathrm{C}_{35}$ над $\mathrm{C}_{34}$. В качестве основной причины отличий между нефтями выделенных семейств авторы рассматривают гипотезу о различии в видовом составе исходной биоты и обстановках диагенеза органического вещества $(\mathrm{OB})$ рифейских очагов генерации УВ на отдельных участках территории.

В результате расширения числа исследованных нефтей первое выделенное в работах $[4,5]$ семейство нефтей пополнено некоторыми нефтями вендских отложений Катангской нефтегазоностной области (НГО) и нефтями юго-западной части Непско-Ботуобинской НГО [6]. Было также выявлено, что каждая группа имеет специфический профиль распределения н-алканов. Характерной чертой нефтей II группы служит явно выраженное преобладание нечетных гомологов в диапазоне $\mathrm{H}_{-} \mathrm{C}_{15}-\mathrm{C}_{20}$, чего не отмечается для нефтей I группы. По составу и распределению полициклических нафтенов систематических различий между выделенными группами нефтей не обнаружено. Корреляция между составом выделенных групп нефтей и рассеянным OB потенциальных нефтематеринских пород показала соответствие между распределением ни изоалканов битумоидов рифейских пород с нефтями I группы и битумоидами вендских пород и нефтями II группы. На основании этого наиболее вероятной причиной различий между нефтями выделенных групп авторы [6] называют связь с разновозрастными нефтематеринскими толщами: рифейскими - для нефтей I группы и вендскими - для нефтей II группы.

В работе [7] показано, что нефти центральной части Восточной Сибири разделяются на два семейства и по другим признакам. Так, к первому семейству отнесены нефти НепскоБотуобинской и Катангской НГО, которые отличаются от других нефтей фанерозоя повышенным относительным содержанием ММА, преобладанием среди стеранов этилхолестанов $\mathrm{C}_{29}$, более низким содержанием изотопа ${ }^{13} \mathrm{C}$, причем Пр и Фт более обогащены изотопом ${ }^{13} \mathrm{C}$, чем $\mathrm{HC}_{17}, \mathrm{HC}_{18}$, и содержат 24-изопропилхолестаны, биологическими предшественниками которых являются клеточные мембраны губок класса Demospongiae [8-10]. Нефти с подобным составом обнаружены в докембрийских нефтях Омана [11], Восточно-Европейской платформы [12] и Индии [13]. Нефти из рифейских отложений Байкитской НГО объединены во второе семейство и содержат меньше стеранов относительно гопанов, больше 24-изопропилхолестанов, меньше MМА и характеризуются более высокими значениями отношения Пр/Фт и близким изотопным составом Пр, Фт и нС $\mathrm{C}_{17}, \mathrm{HC}_{18}$. Наличие 24-изопропилхолестанов свидетельствует о возрасте нефтематеринских толщ не старше 850 млн лет (криоген - поздний рифей), но наличие образцов с низким содержанием 24-изопропилхолестанов говорит о том, что вклад этих отложений был переменным.

Таким образом, в настоящее время идет активное накопление все более новых данных о составе флюидов центральной части Восточной Сибири, позволяющих уточнить палеоэколо- 
гические условия, временные отрезки и локализацию очагов осадконакопления и нефтегенерации, а также оценить вклад различных организмов в ОВ нефтематериских пород.

Используемые для проведения геохимических корреляций УВ составляют лишь небольшую часть нефти. Более полную картину возможно получить только при комплексном подходе с применением большего числа классов соединений, идентифицированных во флюидах. Поэтому нами предпринята попытка найти на едином массиве нефтей центральной части Восточной Сибири признаки их общности и различий по составу насыщенных углеводородов и ароматических соединений.

\section{Материалы и методы}

Для выявления особенностей состава насыщенных и ароматических УВ были исследованы типичные нефти из трех основных НГО центральной части Восточной Сибири: НепскоБотуобинской, Байкитской и Катангской. Географически исследуемый участок расположен в пределах Красноярского края, Иркутской области, Республики Саха-Якутия и охватывает так называемый Золотой пояс Лено-Тунгусской нефтегазоносной провинции. Список и геологическая характеристика образцов нефти приведены в табл. 1.

Таблица 1. Геологическая характеристика образцов нефтей центральной части Восточной Сибири Table 1. Description of investigated oils from Central part of the Eastern Siberia

\begin{tabular}{|c|c|c|c|}
\hline $\begin{array}{c}\text { № } \\
\text { П.П. }\end{array}$ & Площать, № скважины & Глубина отбора, м & Возраст, свита, горизонт \\
\hline 1 & 2 & 3 & 4 \\
\hline \multicolumn{4}{|c|}{ Байкитская НГО } \\
\hline 1 & Юрубченская, 5 & $2285-2295$ & $\mathrm{R}$ \\
\hline 2 & Юрубченская, 8 & $2271-2284$ & R, юрубченксая, I \\
\hline 3 & Вэдрэшевская, 5 & $2329-2360$ & $\mathrm{R}$ \\
\hline 4 & Юрубченская (Главная), 108 & 2500.0 & R, юктенская, I \\
\hline \multicolumn{4}{|c|}{ Катангская НГО } \\
\hline 5 & Джелиндуконская, 103 & $2587-2638$ & V, ванаварская, I, IV \\
\hline 6 & Собинская, 32 & $2648-2651$ & V, ванаварская \\
\hline 7 & Собинская, 14 & $2643-2652$ & V, ванаварская, II \\
\hline 8 & Ванаварская, 1 & $3103,9-3147$ & V, ванаварская, непский \\
\hline \multicolumn{4}{|c|}{ Непско-Ботуобинская НГО } \\
\hline 9 & Кугасская, 364-0 & $1315-1321$ & $\mathrm{E}_{1}$, олекминская, биркинский \\
\hline 10 & Талаканская, 808 & $1067,1-988,1$ & $\mathrm{~V}_{2}-\mathrm{C}_{1}$, билирская, осинский \\
\hline 11 & Центрально-Талаканская, 827 & $1084-1101$ & $\mathrm{~V}_{2}-\mathrm{C}_{1}$, билирская, осинский \\
\hline 12 & Среднеботуобинская, 25 & $1425-1452$ & $\mathrm{~V}_{2}-\mathrm{C}_{1}$, билирская, осинский \\
\hline 13 & Среднеботуобинская, 25 & 1480 & $\mathrm{~V}_{2}-\mathrm{C}_{1}$, билирская, осинский \\
\hline 14 & Верхнечонская, 55 & $1604-1620$ & $\mathrm{~V}_{2}-\mathrm{C}_{1}$, успунская, преображенский \\
\hline 15 & Верхневилючанская, 677 & $1709-1722$ & $\mathrm{~V}_{2}-C_{1}$, юряхская, юряхский \\
\hline 16 & Нижненепская, 187 & $1772-1836$ & $\mathrm{~V}_{2}-\mathrm{C}_{1}$, усольская, осинский \\
\hline 17 & Восточно-Кийская, 181 & $2158-2190$ & $\mathrm{~V}_{2}-\mathrm{C}_{1}$, тэтэрская, усть-кутский \\
\hline 18 & Талаканская, 803 & $1505-1545$ & V, паршинская, хамакинский, Б10 \\
\hline
\end{tabular}


Продолжение табл. 1

Continuation Table 1

\begin{tabular}{|c|c|c|c|}
\hline 1 & 2 & 3 & 4 \\
\hline 19 & Тас-Юряхская, 560 & $1939-1946$ & V, бюкская, ботуобинский \\
\hline 20 & Нелбинская, 2323 & 2055.3 & V, бюкская, ботуобинский \\
\hline 21 & Восточно-Алинское, 304-3П & $1449-1463$ & V, хамакинский-1 \\
\hline 22 & Верхнечонская, 96 & $1612-1620$ & V, паршинская, хамакинский \\
\hline 23 & Иллегинское, 421-1 & $2019-2027$ & $\mathrm{~V}$, хамакинский \\
\hline 24 & Мирнинская, 27 & 2095-2106 & V, бюкская, ботуобинский \\
\hline 25 & Иреляхская, 737 & $2144-2154$ & V, бюкская, ботуобинский \\
\hline 26 & Мирнинская, 736 & $2150-2161$ & V, курсовская, улаханский \\
\hline 27 & Дулисьминская, 4 & $2542-2547$ & V, непская \\
\hline
\end{tabular}

Примечания к табл.: $\mathrm{R}$ - рифей, $\mathrm{V}$ - венд, $\mathrm{C}$ - кембрий.

Состав ациклических алканов был изучен методом газожидкостной хроматографии. Условия анализа описаны в [14]. Анализ циклических насыщенных и ароматических УВ из гексановой фракции нефтей, полученной методом адсорбционной хроматографии на оксиде алюминия (IV степень активности по Брокману), проводили методом хромато-масс-спектрометрии (ХMC) на аппаратном комплексе: хроматограф «Кристалл-5000.2» (Хроматэк) с массспектрометрическим детектором DSQ-II (Termo). Разделение осуществляли на капиллярной хроматографической колонке VF-5ms (VARIAN) (длина колонки 60 м, внутренний диаметр 0,32 мм, толщина пленки неподвижной фазы 0,25 мкм). Температура испарителя $250{ }^{\circ} \mathrm{C}$. Нагрев вели от 80 до $300{ }^{\circ} \mathrm{C}$ со скоростью 3 градуса в минуту. Отдельные соединения идентифицировали по полным масс-спектрам. Для этого использовали спектроструктурные корреляции, имеющиеся в литературе, а также компьютерную библиотеку масс-спектров NIST 2005, содержащую более 190 тыс. соединений.

\section{Результаты и их обсуждение}

Ациклические алканы. В исследованных нефтях идентифицированы алканы нормального строения от $\mathrm{C}_{10}$ до $\mathrm{C}_{35}$, изопреноиды от $\mathrm{C}_{13}$ до $\mathrm{C}_{25}$, а также MМА состава $\mathrm{C}_{19} \mathrm{C}_{30}$. Распределение н-алканов большинства нефтей носит унимодальный характер с максимумами в области $\mathrm{C}_{15} \mathrm{C}_{19}$ (рис. 1). Однако в профиле распределения н-алканов наблюдаются вариации: в нефтях рифея Байкитской НГО концентрации гомологов после максимума плавно снижаются по мере увеличения их молекулярной массы, во всех остальных нефтях наблюдается зигзагообразный профиль распределения н-алканов. В нефтях рифея Байкитской НГО в диапазоне $\mathrm{C}_{16}-\mathrm{C}_{25}$ преобладают четные гомологи и соотношение чет/нечет выше единицы $(1,08-1,20)$, а в большинстве остальных нефтей - нечетные (соотношение чет/нечет 0,84-0,97), в единичных - четные и нечетные н-алканы присутствуют в близких концентрациях (чет/нечет 1,00$1,01)$.

Соотношение н- $\mathrm{C}_{17} / \mathrm{H}-\mathrm{C}_{27}$ во всех образцах значительно выше единицы $(1,6-11,6)$, что характерно для морского типа исходного ОВ. Во всех нефтях н-алканы преобладают над ациклическими изопреноидами, отношение изо-/н-алканы изменяется в интервале 0,1-0,6. 

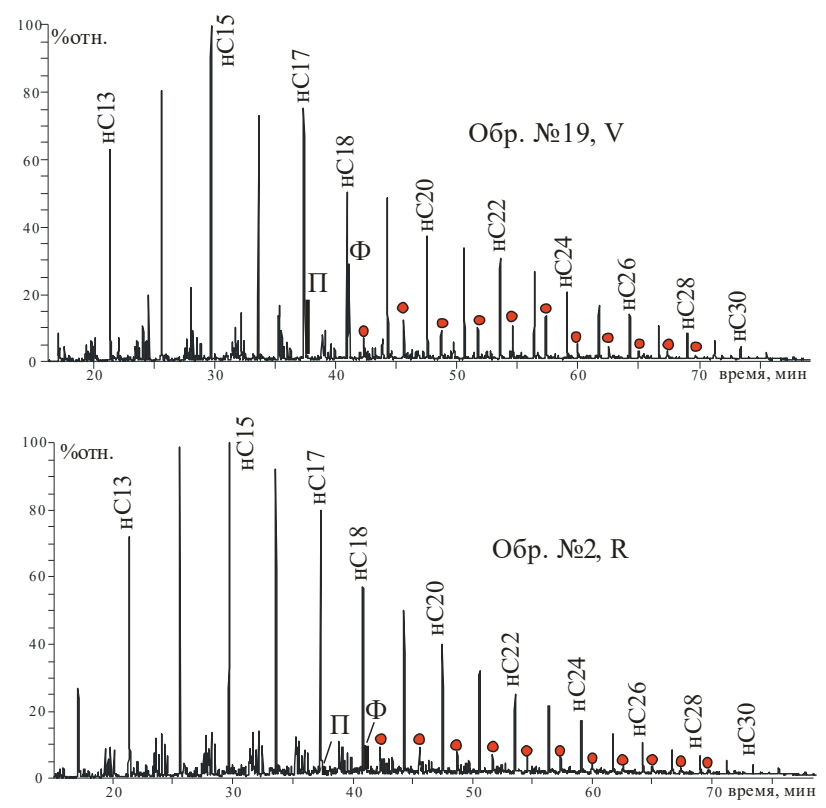

Рис. 1. Хроматограммы насыщенной фракции нефтей; номера образцов соответствуют № п.п. в табл. 1; П - пристан; Ф - фитан; $\mathrm{H}_{15}$ - число атомов углерода в молекуле н-алкана; маркером отмечены 12 - и 13-монометилалканы

Fig. 1. Chromatograms of saturated fractions of oils; sample numbers correspond to numbers in Table 1; $\Pi$-pristane, $\Phi$ - phytane, $\mathrm{nC}_{15}$ - carbon number value in a molecule of n-alkanes, marker - 12- and 13-monomethylalkanes

Нефти рифейских отложений Байкитской НГО обеднены ациклическими изопреноидами и ММА по сравнению с нефтями Катангской и Непско-Ботуобинской НГО. Соотношение н-:изо-:ММА в нефтях Байкитской НГО составляет в среднем 77:16:7, в Катангской - 69:23:9, в Непско-Ботуобинской - 64:25:11. Полученные различия в составе ациклических алканов в нефтях других скважин изученных НГО отмечены также авторами работ [3-7]. Серия гомологов ММА специфически распространена в нефтях протерозоя, их источник не известен, однако в работах [15-17] к организмам предшественникам относят цианобактерии, губки и бесцветные серобактерии. Более низкие содержания ациклических изопреноидов и ММА могут быть вызваны отличием в составе организмов-предшественников исходного ОВ нефтей рифейских отложений Байкитской НГО от венд-кембрийских отложений Непско-Ботуобинской и Катангской НГО.

Во всех образцах нефтей значения отношения П/Ф низкие и меняются в интервале $0,4-1,7$, что соответствует восстановительным и субокислительным условиям формирования исходного $\mathrm{OB}[18]$.

По соотношению изопреноидных и нормальных алканов (рис. 2) нефти рифейских отложений Байкисткой НГО отличаются от остальных повышенной термической зрелостью, на что ранее было указано также в работе [19]. Разновозрастные нефти НепскоБотуобинской НГО и один образец из венда Катангской НГО характеризуются низкими показателями зрелости, а остальные нефти венда Катангской НГО занимают промежуточное положение. 
Циклопентаны. В исследованных нефтях определенны алкилзамещенные производные циклопентана состава $\mathrm{C}_{11}-\mathrm{C}_{29}$. Распределение алкилциклопентанов бимодальное с максимумом на $\mathrm{C}_{14}$ и $\mathrm{C}_{20}$ (рис. 3). Кроме того, содержание $\mathrm{C}_{17}$ выше соседних с ним гомологов. В образцах рифейских отложений Байкитской НГО содержание $\mathrm{C}_{14}$ во всех случаях выше $\mathrm{C}_{20}$, в образцах нефтей из других отложений возможны вариации: ниже, выше либо равны. В образцах Байкитской НГО распределение содержания этих гомологов соответствует ряду $\mathrm{C}_{14}>\mathrm{C}_{17}>\mathrm{C}_{20}$, а в остальных $-\mathrm{C}_{20} \geq \mathrm{C}_{14}>\mathrm{C}_{17}$. Среди гомологов $\mathrm{C}_{16}-\mathrm{C}_{25}$ во всех образцах преобладают четные гомологи (соотношение чет/нечет меняется в интервале 1,23-1,91).

Циклогексаны. Содержание идентифицированных $\mathrm{C}_{11}-\mathrm{C}_{35}$ гомологов алкилзамещенных производных циклогексана меняется пропорционально изменению содержания соответствующих н-алканов и с ростом молекулярной массы падает. Низкомолекулярные гомологи $\mathrm{C}_{13}-\mathrm{C}_{15}$ доминируют над высокомолекулярными (рис. 4), что может являться следствием планктонововодорослевого характера исходного ОВ. Максимум распределения расположен в области

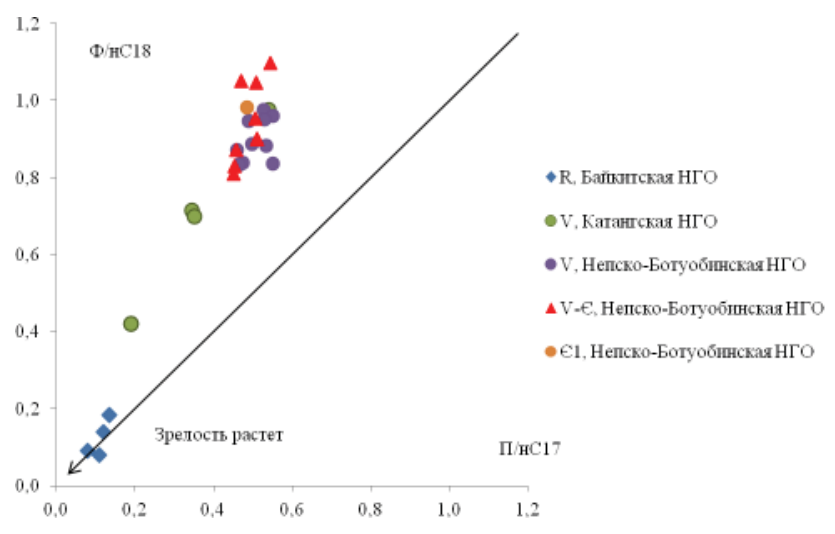

Рис. 2. Зрелость нефтей по соотношению изопреноидных и нормальных алканов

Fig. 2. Maturity of oils: X-Y plot of the phytane/n- $C_{17}$ versus the pristane $/ n-C_{18}$

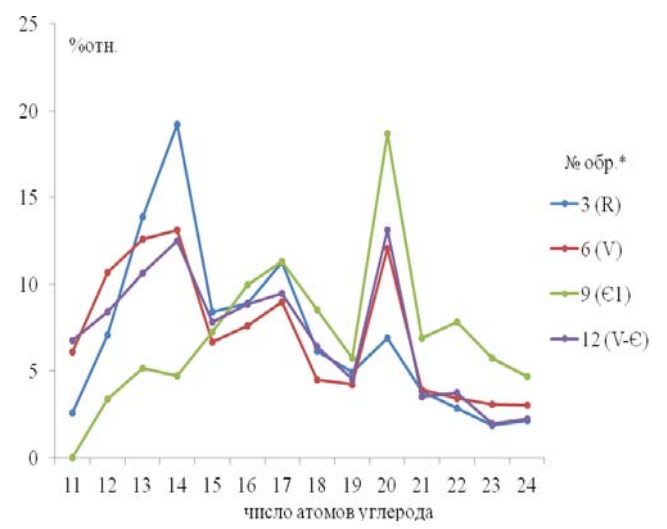

Рис. 3. Распределение алкилциклопентанов в нефтях; * - номера образцов соответствуют № п.п. в табл. 1

Fig. 3. The distribution of alkylcyclopentanes in oils; * sample numbers correspond to numbers in Table 1 
$\mathrm{C}_{13}-\mathrm{C}_{15}$. Как и в составе н-алканов, в большинстве образцов гомологи с нечетным числом атомов углерода преобладают над четными, особенно в области $\mathrm{C}_{16}-\mathrm{C}_{25}$, или четные и нечетные гомологи присутствуют в близкой концентрации (соотношение чет/нечет меняется в интервале 0,83-1,10). Исключение составляют нефти из рифейских отложений Байкитской НГО, в которых преобладают четные алкилциклогексаны (чет/нечет меняется в интервале 1,29-1,41).

Среди циклогексанов идентифицированны также метилалкилциклогексаны, которые представлены м-, п-, о-изомерами. Вариации профиля распределения более однородны, чем для алкилциклогексанов (рис. 5), с максимумом в области $\mathrm{C}_{14}-\mathrm{C}_{17}$ и провалом на $\mathrm{C}_{15}$. Отличий в распределении четных и нечетных гомологов для разновозростных отложений не выявленно, в области $\mathrm{C}_{16}-\mathrm{C}_{25}$ во всех образцах преобладают нечетные гомологи, соотношение чет/нечет меняется в интервале 0,76-0,93.

Tepnaны. Во всех нефтях идентифицированы бициклические (сесквитерпаны) ряда дримана и гомодримана (рис. 6). Свое общее название соединения этого типа по-

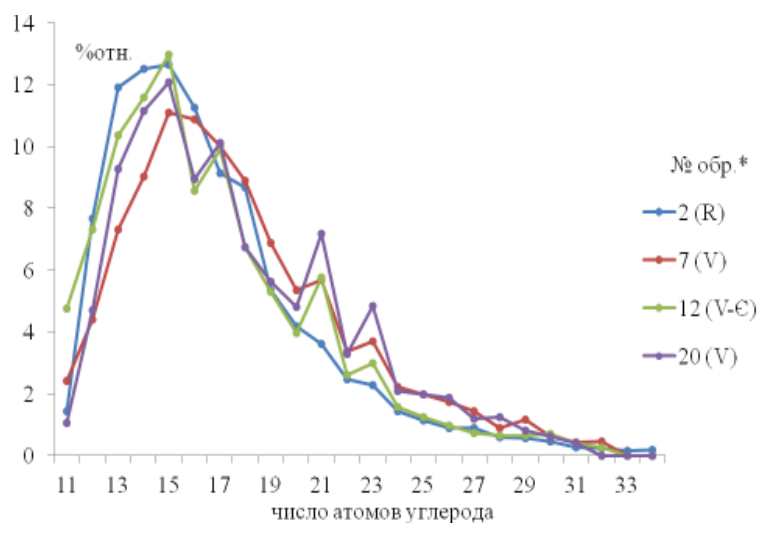

Рис. 4. Распределение алкилциклогексанов в нефтях; * - номера образцов соответствуют № п.п. в табл. 1

Fig. 4. The distribution of alkylcyclohexanes in oils; * sample numbers correspond to numbers in Table 1

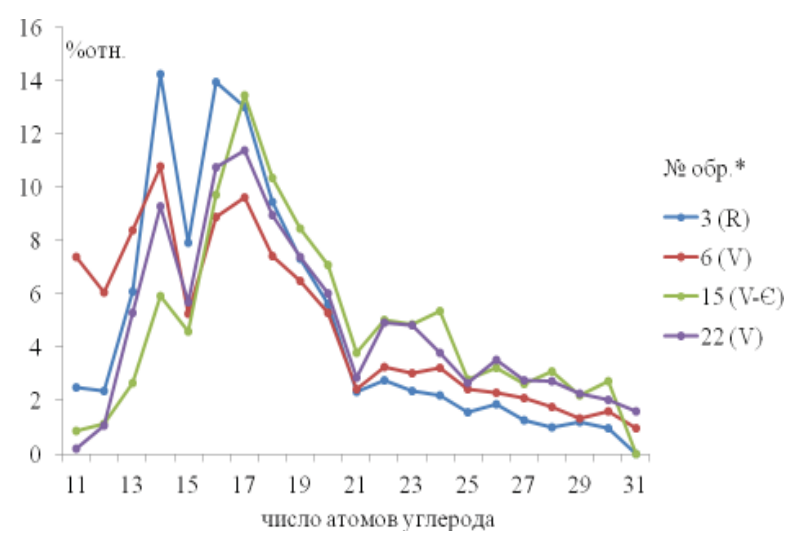

Рис. 5. Распределение метилалкилциклогексанов в нефтях; * - номера образцов соответствуют № п.п. в табл. 1

Fig. 5. The distribution of methylalkylcyclohexanes in oils; * sample numbers correspond to numbers in Table 1 


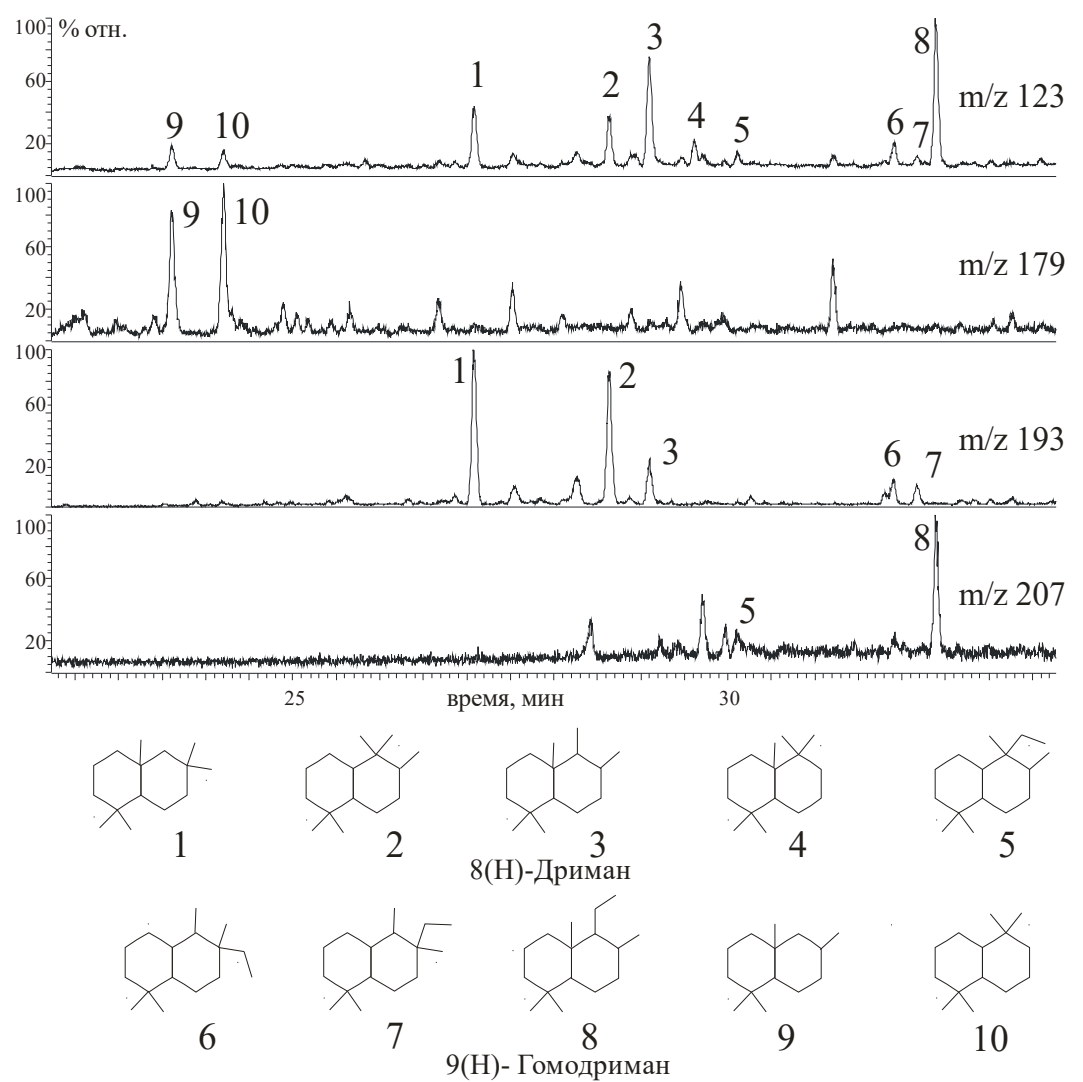

Рис. 6. Распределение дриманов (1-4), гомодриманов $(5-8)$ и нордриманов $(9,10)$ в нефти площади ТасЮряхская, скважина 560, интервал отбора 1939-1946 м (венд)

Fig. 6. Distribution of drimanes (1-4), homodrimanes (5-8) and nordrimanes $(9,10)$ in the oil area TasJuryakhskaya-560, fluid sampling interval 1939-1946 m (Vendian)

лучили от тропических растений рода Drimus, произрастающих в бассейне Тихого океана.

Распределение бициклических терпанов во всех исследованных нефтях однотипно, с максимальным содержанием $8 \beta(\mathrm{H})$-гомодримана и $8 \beta(\mathrm{H})$-дримана. Бициклические сесквитерпаны подобного типа ранее были обнаружены в нефтях Лома-Нова, Анастасиевско-Троицкого $[20,21]$, Сивинского [22] и Иреяхского [23] месторождений, нефтепроявлений в Хакасии и в озере Байкал [24-26], в ряде австралийских и западно-сибирских нефтях [27, 28]. Многие исследователи считают, что соединения с подобными структурами тесно связаны с терпенами высшей растительности, однако авторы [18] рекомендовали с осторожностью использовать эту группу биомаркеров в качестве показателей «континентальности» исходного ОВ, так как дриманы и гомодриманы широко распространены в прокариотических организмах [27, 29]. Лактоны дриманов обнаружены у метаболита грибов-базидиомицетов. Близкие дриманам структуры фуродизанов выделены также из губок рода Dysidea. Современным биогенетическим предшественником циклических сесквитерпеноидных соединений считается пирофосфат фарнезола. В результате циклизации его производного - фарнезана образуется бициклофарнезан (дриман) [30]. 
Наряду с бициклическими в изученных нефтях определены три-, тетра- и пентациклические терпаны. Среди трициклических терпанов во всех исследованных нефтях преобладают $\mathrm{C}_{23}$ (рис. $7 A$ ), присутствуют тетрациклический терпан $\mathrm{C}_{24}$ и пентациклический гаммацеран $\mathrm{C}_{30}$, свидетельствующие о формировании исходного ОВ в условиях повышенной солености.

Доминирующей группой терпанов в нефтях являются пентациклические структурные аналоги гопана, представленные гомологами $\mathrm{C}_{27} \mathrm{C}_{35}$. Повышенная концентрация гомогопанов $\mathrm{C}_{35}$ по сравнению с гомогопанами $\mathrm{C}_{34}$ указывает на морские условия седиментации и восстановительную обстановку в диагенезе. Величины соотношения изомеров трисноргопанов $\mathrm{Ts} /(\mathrm{Ts}+\mathrm{Tm})$, часто зависящие от термической преобразованности $\mathrm{OB}$, меняются в интервале 0,37-0,55 и в среднем составляют 0,47. При этом корреляции между этими величинами и возрастом вмещающих отложений не выявлено. Это может быть следствием влияния на соотношение $\mathrm{Ts} /(\mathrm{Ts}+\mathrm{Tm})$ не только термодинамических факторов, но литолого-фациальных условий осадконакопления [18]. Соотношение $\mathrm{S}$ и $\mathrm{R}$ эпимеров гомогопана $\mathrm{C}_{31}$ близко к равновесному и в среднем составляет 0,53 , что соответствует термически зрелым нефтям. Кроме того, в нефтях обнаружена группа 8,14-секогопанов (m/z 123) состава $\mathrm{C}_{27}-\mathrm{C}_{34}$. Секогопаны генетически связаны с гопанами и могли образоваться из последних вследствие различных термокаталитических превращений [31].

Прегнаны и стераны. Прегнаны представлены гомологами $\mathrm{C}_{21}$ и $\mathrm{C}_{22}$ (рис. 7Б), их высокие концентрации во всех образцах нефти (7-18 \% отн.) могут быть обусловлены повышен-

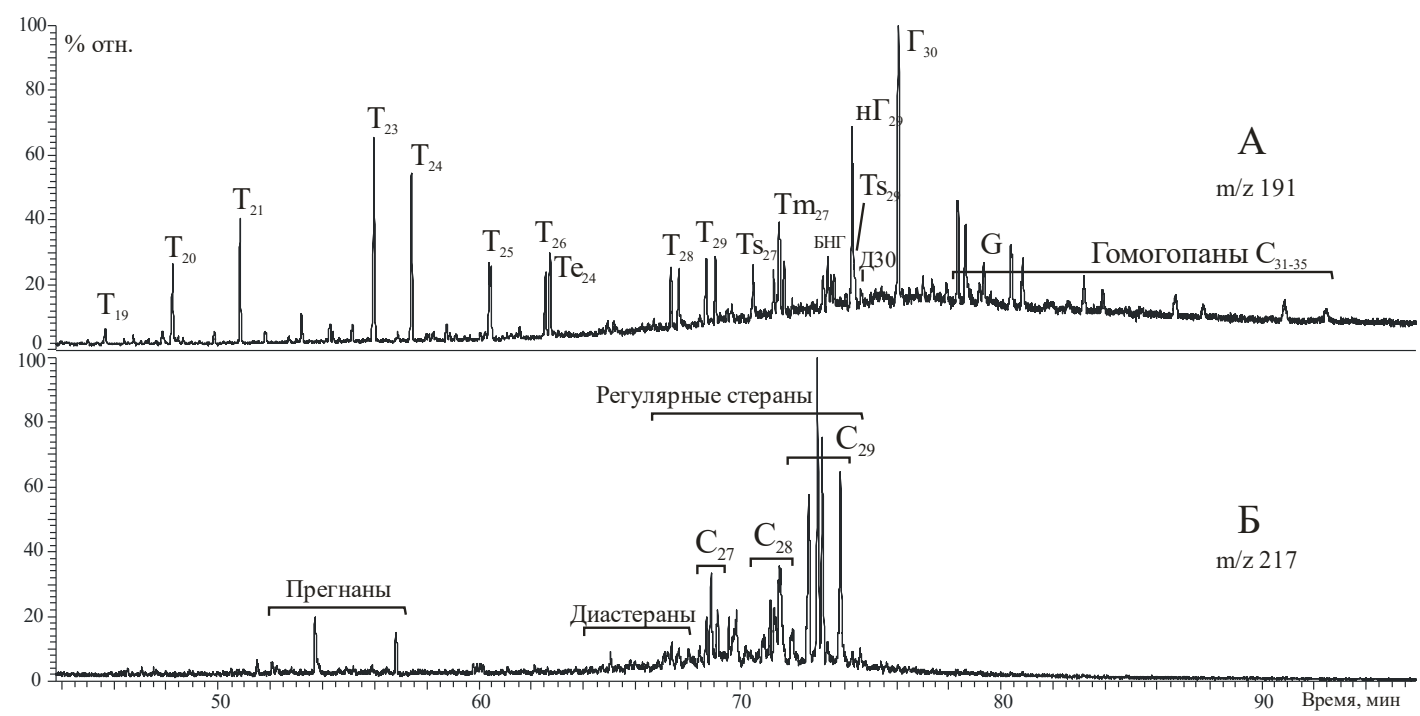

Рис. 7. Масс-фрагментограммы стеранов и терпанов нефти площади Тас - Юряхская, скважина 560, интервал отбора 1939-1946 м (венд). Обозначения: Т - трициклические терпаны $\mathrm{C}_{21-29}$, Те тетрациклический терпан $\mathrm{C}_{24}$, Ts - $18 \alpha, 21 \beta$ - норнеогопаны $\mathrm{C}_{27}, \mathrm{C}_{29}$; $\mathrm{Tm}-17 \alpha, 21 \beta-$ Трисноргопан $\mathrm{C}_{27}$;

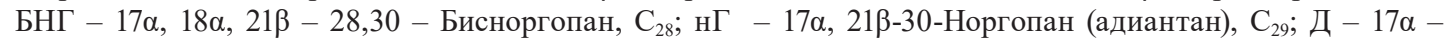
диагопан $\mathrm{C}_{30} ; \Gamma-17 \alpha, 21 \beta$ - гопан $\mathrm{C}_{30} ; \mathrm{G}$ - гаммацеран

Fig. 7. Mass-chromatograms of steranes and hopanes in oil from Tas-Juryahskaya-560, fluid sampling interval 1939-1946 m (Vendian). Legend: $\mathrm{T}$ - tricyclic terpanes $\mathrm{C}_{21-29}, \mathrm{Te}-$ tetracyclic terpanes $\mathrm{C}_{24}$, $\mathrm{Ts}-18 \alpha$, $21 \beta$-norneohopanes $\mathrm{C}_{27}, \mathrm{C}_{29}$; Tm - 17 $\alpha, 21 \beta$-Trisnorhopanes $\mathrm{C}_{27} ;$ БHГ - 17 $\alpha, 18 \alpha, 21 \beta$-28,30-Bisnorhopane, $\mathrm{C}_{28}$; ${ }_{\mathrm{H}} \Gamma-17 \alpha, 21 \beta-30$-Norhopane, $\mathrm{C}_{29} ;$ Д-17 $\alpha$-diahopane $\mathrm{C}_{30} ; \Gamma-17 \alpha, 21 \beta$-hopane $\mathrm{C}_{30} ; \mathrm{G}$ - gammacerane

$$
-239-
$$


ной соленостью бассейна осадконакопления. Среди гомологов стеранов преобладают этилхолестаны (рис. 7Б), что свидетельствует о значительном вкладе морских зеленых водорослей в исходное ОВ [18]. Однако для нефтей рифейских отложений Байкитской НГО и вендских Катангской НГО характерно меньшее содержание этилхолестанов (45-48 \%) и большее холестанов (25-30 \%) по сравнению с нефтями Непско-Ботуобинской НГО (50-55 \% и 17-21 \% соответственно). По составу стеранов и низким значениям отношения диастеранов к регулярным $(0,11-0,49)$ можно предположить, что исходное ОВ всех исследованных нефтей формировалось в карбонатных фациях мелководного морского бассейна. Значения коэффициентов созревания К1 $(0,45-0,51)$ и К2 $(1,79-3,66)$, рассчитанные по составу стеранов $(\mathrm{K} 1(\alpha \alpha, \beta \beta \mathrm{C} 29)=20 \mathrm{~S} /(20 \mathrm{~S}+20 \mathrm{R})$, $(\mathrm{K} 2(\mathrm{C} 29)=\beta \beta(20 \mathrm{~S}+20 \mathrm{R}) / \alpha \alpha 20 \mathrm{R}))$, соответствуют средним стадиям катагенеза $\mathrm{MK}_{1}-\mathrm{MK}_{2}$ [32-34].

Алкилбензоль. Во всех изученных образцах идентифицированы н-алкилбензолы (АБ) и их метил- (МАБ), этил- (ЭАБ) и диметил(ДМАБ)производные (m/z 91, 105, 119). В нефтях также содержатся алкилбензолы, содержащие изопреноидную алифатическую цепь $\mathrm{C}_{20}$, - фитанилбензол (ФтБ) и его метил- (МФтБ) и диметил(ДМФтБ)замещенные гомологи (m/z 92, 120, 134). Средние значения относительного содержания отдельных групп АБ в нефтях по возрастам вмещающих их отложений представлены на рис. $8 A$. Во всех нефтях наибольшая доля приходится на МАБ, их содержание меняется в диапазоне 42,7-58,1 \%. В нефтях Непско-Ботуобинской НГО $(\mathrm{V}, \mathrm{V}-\mathrm{C})$ концентрация отдельных групп АБ снижается в ряду МАБ $>$ АБ $\geq[$ ЭАБ+ДМАБ] $>$ ФтБ. В нефтях рифея Байкитской НГО и венда Катангской НГО - МАБ > [ЭАБ+ДМАБ] $\geq$ АБ > ФтБ. По средним значениям можно сказать, что с увеличением возраста вмещающих отложений доля АБ и ФтБ в нефтях падает, а МАБ, [ЭАБ + ДМАБ] - растет.

Среди АБ преобладают низкомолекулярные гомологи с максимальным содержанием $\mathrm{C}_{17}$ и $\mathrm{C}_{21}[14,35]$. В нефтях венд-нижнекембрийских отложений Катангской и Непско-Ботуобинской НГО преобладают АБ $\mathrm{C}_{17}, \mathrm{C}_{21}$, причем концентрация $\mathrm{C}_{21}$ выше, чем $\mathrm{C}_{17}$. Для нефтей рифейских отложений Байкитской НГО характерен широкий максимум в области $\mathrm{C}_{13}$ - $\mathrm{C}_{17}$ (их суммарное содержание составляет около 50 \% отн.) и невысокие концентрации $\mathrm{C}_{21}$ (около 7,4-9,7 \%). Это отличает их от нефтей из более молодых отложений, в которых содержание $\mathrm{C}_{21}$ составляет $15-22 \%$ отн. (рис. 9). Таким образом, в нефтях рифея соотношение гомологов АБ $\mathrm{C}_{13}, \mathrm{C}_{17}, \mathrm{C}_{21}$ отличается от остальных нефтей, и по соотношению АБ $\mathrm{C}_{17} / \mathrm{C}_{21}$ и $\mathrm{C}_{13} / \mathrm{C}_{21}$ они выделяются в отдельную группу (рис. 10).
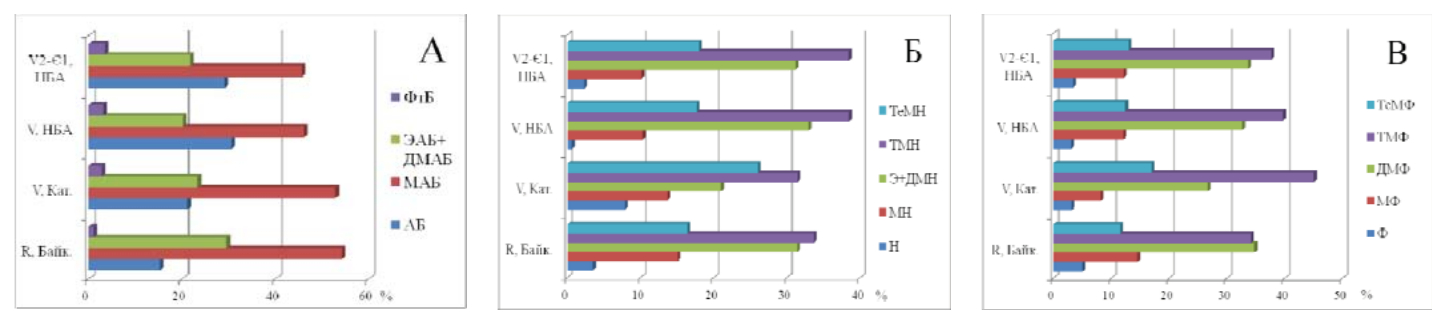

Рис. 8. Относительное содержание отдельных групп соединений в составе аренов: (А) алкилбензолов, (Б) нафталинов, (В) фенантренов. Обозначения: НБА - Непско-Ботуобинская НГО; Кат. - Катангская НГО; Байк. - Байкитская НГО

Fig. 8. Relative content of specified groups of aromatic hydrocarbons in oils: (A) alkylbenzenes, (B) naphthalenes, (B) phenanthrenes. Legend: HBA - Nepa-Botuobin PBR; Кат. - Katanga PBR; Байк. - Bakit PBR 


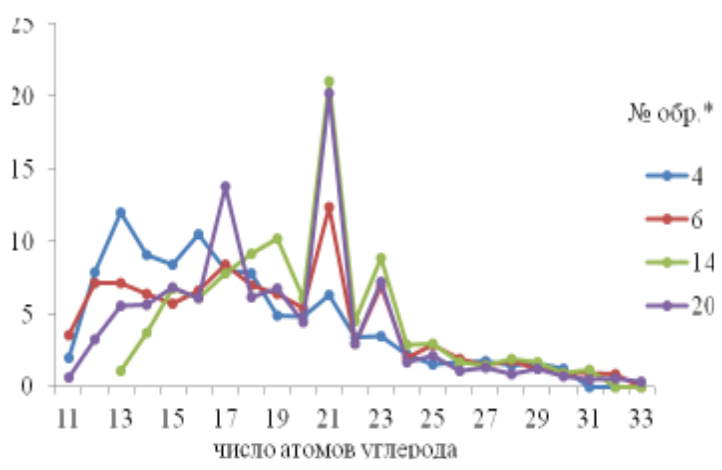

Рис. 9. Распределение алкилбензолов (m/z 91) в нефтях; * - номера образцов соответствуют № п.п. в табл. 1

Fig. 9. Distribution of alkylbenzenes (m/z 91) in oils; * - sample numbers correspond to numbers in Table 1
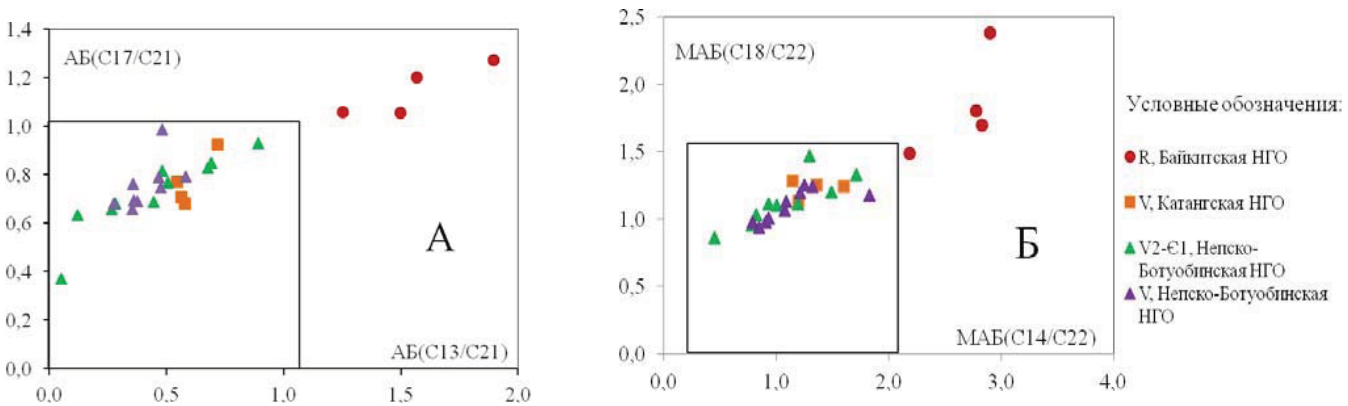

Рис. 10. Распределение нефтей центральной части Восточной Сибири по соотношению гомологов алкилбензола $\mathrm{C}_{13} / \mathrm{C}_{21}$ и $\mathrm{C}_{17} / \mathrm{C}_{21}$ и метилалкилбензола $\mathrm{C}_{14} / \mathrm{C}_{22}$ и $\mathrm{C}_{18} / \mathrm{C}_{22}$

Fig. 10. The distribution of the oils by the ratio of the alkylbenzenes $C_{13} / C_{21}$ and $C_{17} / C_{21}$ and methylalkylbenzenes $\mathrm{C}_{14} / \mathrm{C}_{22}$ and $\mathrm{C}_{18} / \mathrm{C}_{22}$

Аномально высокие концентрации АБ $\mathrm{C}_{21}$ в нефтях авторы [15] связывают с возможным предшественником этого соединения - полиолефином $\mathrm{C}_{21} \mathrm{H}_{32}$ с шестью двойными связями (генэйкоза-3,6,9,12,15,18-гексаен) [36], которое содержится в планктонных водорослях. Соотношение чет/нечет в области $\mathrm{C}_{16}-\mathrm{C}_{25}$ в нефтях рифея Байкитской НГО близко к единице, в остальных не превышает 0,7 (т.е. преобладают нечетные гомологи).

В составе МАБ 1,4-, 1,2-, 1,3-метилзамещенные изомеры присутствуют преимущественно низкомолекулярные гомологи $\mathrm{C}_{12}-\mathrm{C}_{22}$ (рис. 11). Для нефтей Непско-Ботуобинской НГО максимум приходится на $\mathrm{C}_{18}$ и $\mathrm{C}_{22}$, а для нефтей Катангской и Байкитской НГО характерен широкий максимум в области $\mathrm{C}_{13}-\mathrm{C}_{18}$. Интересно, что среди МАБ нефтей с высокими концентрациями $\mathrm{C}_{18}$ и $\mathrm{C}_{22}$ в области $\mathrm{C}_{16}-\mathrm{C}_{25}$ доминируют соединения с четным числом атомов углеродов в молекуле. Но в нефтях рифея Байкитской НГО преобладание четных гомологов менее выражено, соотношение чет/нечет составляет 1,0-1,2, тогда как в остальных нефтях 1,3-1,7. Близкие картины распределения в нефтях Восточной Сибири гомологов АБ и МАБ с одинаковым числом атомов углерода в алкильном заместителе (рис. 10) согласуются с данными [37], свидетельствующими о тесной связи механизмов формирования обеих серий. 
Отношение м-/о-МАБ, предложенное в качестве индикатора термальной зрелости нефтей $[38,39]$, демонстрирует хорошую корреляцию с отношениями н- $\mathrm{C}_{17} /$ П и н- $\mathrm{C}_{18} /$ Ф. Более высокими значениями этого показателя зрелости, меняющимися в интервале $0,75-0,82$, характеризуются нефти рифея Байкитской НГО, тогда как остальные нефти имеют значения 0,42-0,57 (за единичным случаем 0,62 - Дулисьминская, скв. 702).

Распределение ЭАБ и ДМАБ имеет более однородный характер. Для всех изученных образцов характерен широкий максимум в области $\mathrm{C}_{14}-\mathrm{C}_{17}$, в диапазоне $\mathrm{C}_{16}$ - $\mathrm{C}_{21}$ преобладают четные гомологи.

Нафталины. Во всех исследованных нефтях по m/z 128, 142, 156, 170, 184 идентифицированы нафталин и его метилзамещенные гомологи, содержащие от 1 до 4 метильных заместителя (рис. 12). Средние значения относительного содержания отдельных групп нафталинов по возрастам представлены на рис. 8Б. В нефтях рифея Байкитской НГО доминируют этил- (ЭН)

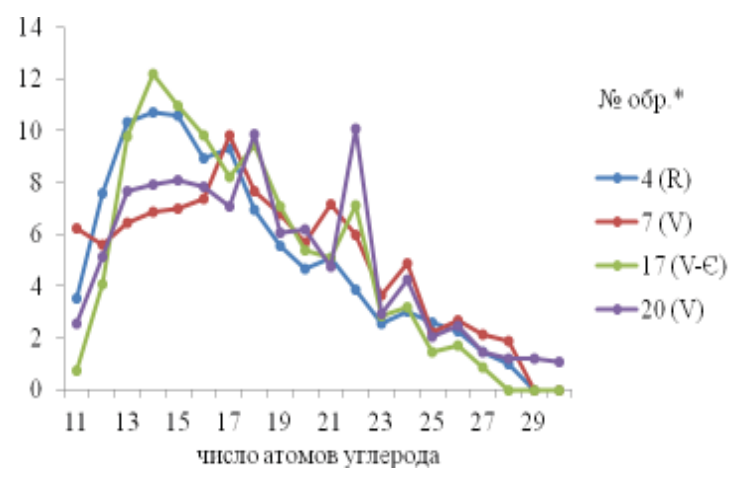

Рис. 11. Распределение метилалкилбензолов (m/z 105) в нефтях. * - номера образцов соответствуют № п.п. в табл. 1

Fig. 11. Distribution of methylalkylbenzenes (m/z 105) in oils; * - sample numbers correspond to numbers in Table 1

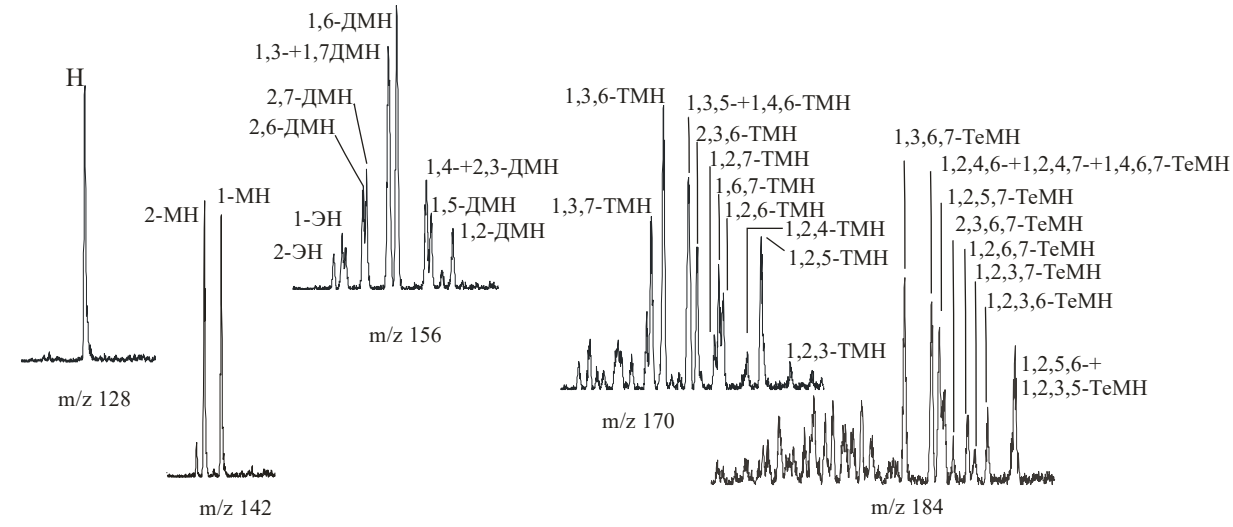

Рис. 12. Масс-хроматограммы, показывающие распределение алкилнафталинов (m/z 128, 142, 156, 170, 184) в нефти Джелиндуконской площади, скважина 103, интервал отбора 2587-2638 м (венд)

Fig. 12. Mass-chromatograms of alkylnaphthalenes (m/z 128, 142, 156, 170, 184) in oil Jelindukonskaya-103, fluid sampling interval 2587-2638 m (Vendian) 
и диметил (ДМН) нафталины, их суммарное содержание варьирует в диапазоне 30,9-35,4 \% отн. В остальных нефтях доминируют триметилнафталины (ТМН), их содержание меняется в интервале 28,9-43, \% отн. В нефтях рифея Байкитской НГО концентрация отдельных групп нафталинов снижается в ряду: [ЭН+ДМН] > ТМН > ТеМН (тетраметилнафталины) $\geq \mathrm{MH}>\mathrm{H}$; в нефтях из венда Катангской НГО: ТМН> ТеMН $\geq[$ ЭЭ+ДМН $]>$ MH >Н: в остальных нефтях: $\mathrm{TMH}>[Э \mathrm{H}+Д \mathrm{MH}]>\mathrm{TeMH}>\mathrm{MH}>\mathrm{H}$.

Параметры термической зрелости, основанные на изомеризации термодинамически менее устойчивых $\alpha$-алкилнафталинов в термодинамически более устойчивые $\beta$-алкилнафталины (MNR, DNR-1, TNR-1, TNR-2) [40] увеличиваются при переходе от венд-кембрийских нефтей к рифейским (рис. $13 A$, Б).

Фенантрены. По m/z 178, 194, 206, 220, 234 в нефтях идентифицированы фенантрен и его гомологи, содержащие в качестве боковых заместителей от 1 до 4 метильных групп (рис. 14). Во всех образцах доминируют диметил- (ДМФ) и триметил-(ТМФ)фенантрены. В нефтях из рифейских отложений ДМФ и ТМФ содержатся в близких концентрациях (31,0-37,8 \% отн.), а в остальных доминирует ТМФ (33,4-49,4 \% отн.) (рис. $8 B$ ). В нефтях из рифейских отложений Байкитской НГО концентрация отдельных групп фенантренов снижается в ряду ДМФ $\geq$ ТМФ > $>$ МФ > ТеМФ > Ф. В остальных нефтях: ТМФ > ДМФ > ТеМФ $\geq$ МФ > Ф.
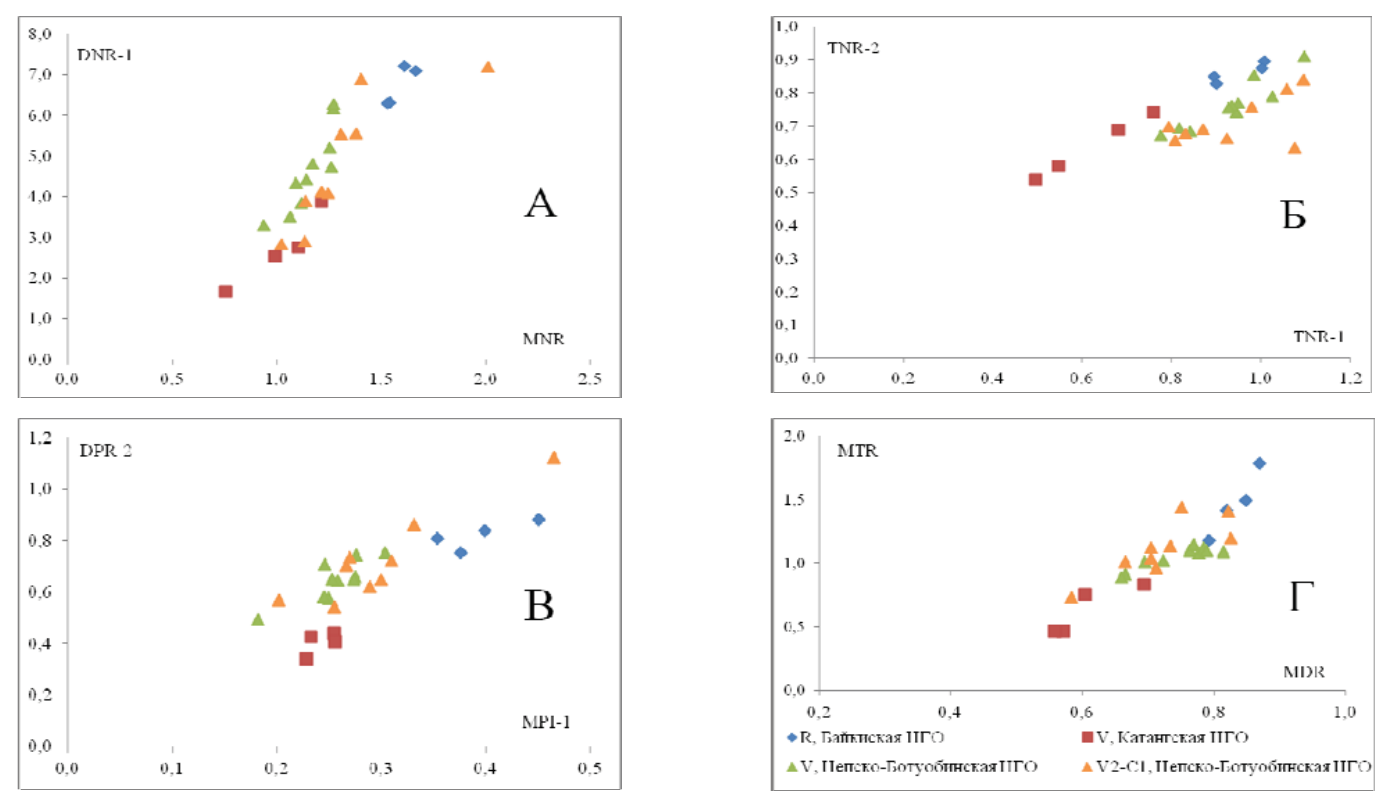

Рис. 13. Параметры термической зрелости нефтей, рассчитанные на основе состава метилпроизводных нафталина и фенантрена: MNR = 2-MH/1-MH; MNR = 2-MH/1-MH; DNR-1 = (2,6-+2,7-ДМН)/1,5ДМН; ТNR-1 = 2,3,6-ТМН/(1,3,5-+1,4,6-TMH); TNR-2 = $(1,3,7-+2,3,6-\mathrm{TMH}) /(1,3,5-+1,3,6-+1,4,6-\mathrm{TMH}))$; MPI-1 = 1,5*(2-+3-MФ)/(Ф+1-+9-МФ); DPR = (3,5-+2,6-+2,7-ДМФ)/(1,3-+3,9-+2,10-+3,10-+1,6-+2,9-+2,5-ДМФ); $\mathrm{MDR}=\Sigma \mathrm{M} \Phi / \Sigma Д \mathrm{M} \Phi ; \mathrm{MTR}=\Sigma \mathrm{M} \Phi / \Sigma \mathrm{TM} \Phi$

Fig. 13. Parameters of thermal maturity in oils calculated by the composition of methyl-substituted naphthalene and phenanthrene: $\mathrm{MNR}=2-\mathrm{MH} / 1-\mathrm{MH} ; \mathrm{MNR}=2-\mathrm{MH} / 1-\mathrm{MH} ; \mathrm{DNR}-1=(2,6-+2,7-Д \mathrm{MH}) / 1,5-Д \mathrm{MH}$; TNR-1 = 2,3,6-TMH/(1,3,5-+1,4,6-TMH); TNR-2 = (1,3,7-+2,3,6-TMH $) /(1,3,5-+1,3,6-+1,4,6-\mathrm{TMH})$; MPI-1 = 1,5*(2-+3-MФ)/(Ф+1-+9-MФ); DPR = (3,5-+2,6-+2,7-ДМФ)/(1,3-+3,9-+2,10-+3,10-+1,6-+2,9-+2,5-ДМФ); $\mathrm{MDR}=\Sigma \mathrm{M} \Phi / \Sigma Д \mathrm{M} \Phi ; \mathrm{MTR}=\Sigma \mathrm{M} \Phi / \Sigma \mathrm{TM} \Phi$ 


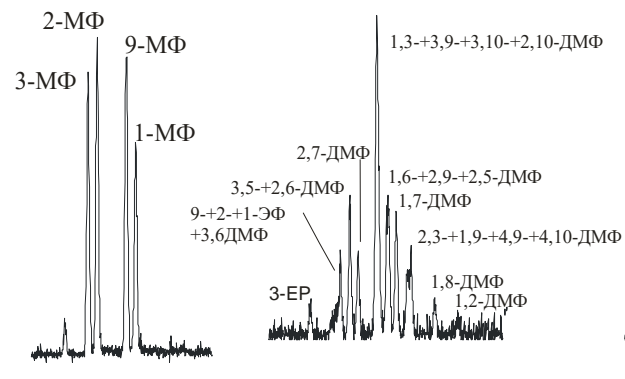

$\mathrm{m} / \mathrm{z} 192$

$\mathrm{m} / \mathrm{z} 206$

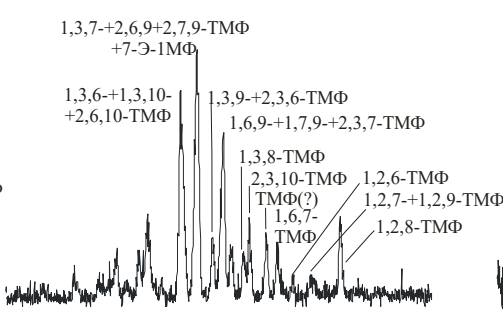

$\mathrm{m} / \mathrm{z} 220$

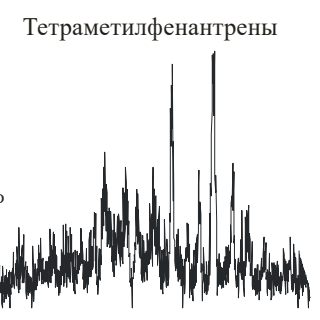

$\mathrm{m} / \mathrm{z} 234$

Рис. 14. Масс-хроматограммы, показывающие распределение алкилфенантренов (m/z 192, 206, 220, 234) в нефти Собинской площади, скважина 14, интервал отбора 2643-2652 м (венд)

Fig. 14. Mass-chromatograms of alkylphenanthrenes (m/z 192, 206, 220, 234) in oil Sobinskaya-14, fluid sampling interval 2643-2652 m (Vendian)

Отношения MPI-1, DPR [40], основанные на реакциях изомеризации метильного заместителя из $\alpha$ - в энергетически более выгодные $\beta$-положения в ароматическом кольце фенантрена так же, как и параметры зрелости, рассчитанные по нафталинам, повышены для нефтей из рифея Байкитской НГО (рис. 13B). Минимальные значения этих параметров зафиксированы для нефтей из вендских отложений Катангской НГО, аномально высокие - для нефти № 10, 17 $\left(\mathrm{V}_{2}-\mathrm{C}_{1}\right.$, Непско-Ботуобинская НГО). Однако в целом параметры термической зрелости фенантренов понижены по сравнению с нафталинами, что, возможно, связано с менее интенсивными процессами изомеризации фенантренов.

Параметры MDR и MTR (рис. 13Г), основанные на деметилировании ДМФ и ТМФ в соответствующие МФ, согласуются с параметрами MPI-1, DPR. Причем деметилирование ТМФ протекало более интенсивно, чем ДМФ. Расчетная отражательная способность витринита $\mathrm{Rc}=0,6 \times 1,5 \times(2-\mathrm{MP}+3-\mathrm{MP}) /(\mathrm{P}+9-\mathrm{MP}+1-\mathrm{MP})+0,4$ [41] для большинства нефтей соответствует пику нефтяного окна $0,72-0,90 \%$, а для нефтей вендских отложений Катангской НГО - ранней стадии нефтяного окна 0,65-0,66 \%.

\section{Заключение}

В результате проведенных исследований по совокупности параметров состава насыщенных и ароматических соединений нами выделены две группы нефтей. К первой группе отнесены нефти венд-нижнекембрийских отложений Катангской и Непско-Ботуобинской НГО, ко второй - нефти рифейских отложений Байкитской НГО.

Выделенные группы нефтей имеют специфический профиль распределения н-алканов, циклопентанов, циклогексанов, н-алкилбензолов, нафталинов, фенантренов и их метилзамещенных гомологов.

В отличие от нефтей первой группы в нефтях второй в молекулярно-массовом распределении н-алканов, насыщенных и ароматических УВ с длинным алкильным заместителем, в диапазоне $\mathrm{C}_{16}-\mathrm{C}_{25}$ преобладают четные гомологи.

Состав всех исследованных групп соединений указывает на большую термическую преобразованность нефтей из рифея Байкитской НГО. Но параметры зрелости, рассчитанные на основе состава н- и изо-алканов, м- и о-замещенных метилалкилбензолов и гомологов нафта- 
линов и фенантренов, показывают большую контрастность, нежели показатели по составу стеранов и терпанов.

\section{Список литературы}

1. Геология нефти и газа Сибирской платформы. Под ред. Конторовича А.Э., Суркова В.С., Трофимука А.А. М.: Недра, 1981. 552 с. [Geology of oil and gas of the Siberian platform. Under Ed. Kontorovich A.E., Surkov V.S., Trofimuk A.A. Moscow: Nedra, 1981. 552 p. (In Russ.)]

2. Семихатов М.А. В кн.: Дополнение $\kappa$ стратиграфическому кодексу России. СПб.: ВСЕГЕИ, 2000. с. 95-107. [Semikhatov М.А. In: Supplement to the stratigraphic code of Russia. Saint Petersburg: VSEGEI, 2000. P. 95-107. (In Russ.)]

3. Неручев С.Г., Баженова Т.К., Смирнов С.В. и др. Оиенка потенциальных ресурсов углеводородов на основе моделирования процессов их генераџии, мигращии и аккумулящии. СПб.: Недра, 2006. 364 с. [Neruchev S.G., Bazhenova T.K., Smirnov S.V. et al. Evaluation of potential hydrocarbon resources on the basis of modeling processes of their generation, migration and accumulation. Saint Petersburg: Nedra, 2006. 364 p. (In Russ.)]

4. Конторович А.Э., Меленовский В.Н., Тимошина И.Д., Махнева Е.А. Семейства верхнедокембрийских нефтей Сибирской платформы. Докл. РАН 2000, Т. 370(1), С. 92-95. [Kontorovich A.E., Melenevskii V.N., Timoshina I.D., Makhneva E.A. Family upper Precambrian oils of the Siberian platform. Dokl. Russian Academy of Sciences 2000, T. 370(1), P. 92-95. (In Russ.)]

5. Тимошина И.Д. Геохимия органического вещества нефтепроизводивших пород и нефтей верхнего докембрия юга Восточной Сибири. Геология и геофизика 2004, Т. 45(7), С. 901-910. [Timoshina I.D. Geochemistry of organic matter of oil source rocks and oils from upper Precambrian strata of southern East Siberia. Geology and Geophysics 2004, T. 45(7), P. 901-910. (In Russ.)]

6. Дахнова М.В., Жеглова Т.П., Можегова С.В., Мялкина Ю.А., Назарова Е.С., Нечитайло Г.Е. Роль рифейских и вендских нефтематеринских толщ как поставщиков углеводородов в зоны нефтенакопления на юге Сибирской платформы. Усnехи органической геохимии. Материалы конференции 11-15 октября 2010 2. Новосибирск, 2010. С. 129-132. [Dakhnova M.V., Zheglova T.P., Mozhegova S.V., Markina J.A., Nazarova E.S., Nechitaylo, G.E. the Role of the Riphean and Vendian oil source strata as suppliers of hydrocarbons in the zone of oil accumulation to the South of the Siberian platform. The success of organic Geochemistry. Materials of the conference 11-15 October 2010, Novosibirsk, 2010. P. 129-132.

7. Kelly A.E., Love G.D., Zumberge J.E., Summons R.E. Hydrocarbon biomarkers of Neoproterozoic to Lower Cambrian oils from eastern Siberia. Organic Geochemistry 2011. Vol. 42(6), P. 640-654.

8. Fowler M.G., Douglas A.G. Saturated hydrocarbon biomarkers of Late Precambrian age from East Siberia. Organic Geochemistry 1987. Vol. 11, P. 201-213.

9. Summons R.E., Powell T.G. Hydrocarbon composition of the Late Proterozoic oils of the Siberian Platform: Implications for the depositional environment of the source rocks. In: Schidlowski M., Golubic S., Kimberley M.M., McKirdy D.M., Trudinger P.A. (Eds.). Early Evolution and Mineral and Energy Resources. Springer Verlag, Berlin, 1992. P. 296-307.

10. Grosjean E., Love G.D., Stalvies C., Fike D.A., Summons R.E. New oil-source rock correlations in the South Oman Salt Basin. Organic Geochemistry 2009. Vol. 40, P. 87-110. 
11. Grantham P.J., Lijmbach J., Posthuma J., Hughes Clarke M.W., Willink R.J. Origin of crude oils in Oman. Journal of Petroleum Geology 1988. Vol. 11, P. 61-88.

12. Bazhenova O.K., Arefiev O.A., Geochemical peculiarities of Pre-Cambrian source rocks in the East European Platform. Organic Geochemistry 1996. Vol. 25, P. 341-351.

13. Peters K.E., Clark M.E., Das Gupta U., McCaffrey M.A., Lee C.Y. Recognition of an Infracambrian rock based on biomarker in the Baghewala-1 oil, India. American Association of Petroleum Geologists Bulletin 1995. Vol. 79, P. 1481-1493.

14. Akhmedova A.R., Serebrennikova O.V., Shiganova O.V. Composition of Mono-, Bi- and Tricyclic Aromatic Hydrocarbons in Oils from the Middle part of the East Siberia. Journal of Siberian Federal University: Chemistry 2010. Vol. 3(4), P. 329-339.

15. Shiea S.C. Brassell and Ward D.M. Mid-chain branched mono- and dimethyl alkanes in hot spring cyanobacterial mats. A direct biogenic source for branched alkanes in ancient sediments? Organic Geochemistry 1990. Vol. 15, P. 223-231.

16. Thiel V., Jenisch A., Wörheide G., Löwenberg A., Reitner J. and Michaelis W. Mid-chain branched alkanoic acids from "living fossil" demosponges: a link to ancient sedimentary lipids? Organic Geochemistry 1999. Vol. 30, P. 1-14.

17. Love G.D., Stalvies C., Grosjean E., Meredith W. and Snape C.E. Analysis of molecular biomarkers covalently bound within Neoproterozoic sedimentary kerogen, In: Kelley P.H., Bambach R.K. Editors Paleontological Society Papers: The Paleontological Society 2008. Vol. 14, P. 67-83.

18. Peters K.E., Walters C.C. and Moldowan J.M. The Biomarker Guide (second ed.). Cambridge: Cambridge University Press, 2005. 1156 p.

19. ten Haven H.L., de Leeuw J.W., Rullkötter J. and Sininnghe Damsté J.S. Restricted utility of the pristine/phytane ratio as a palaeoenvironmental indicator. Nature 1987. Vol. 330, P. 641643.

20. Bendoraitis J. Hydrocarbons of biogenic origin in petroleum, aromatic triterpenes and bicyclic sesquiterpenes. In: Advances in organic geochemistry. Paris, Editions Technip 1974. P. 209-224.

21. Каграманова Г.Р., Пустильникова С.Д., Пехк Т.И., Денисов Ю.В., Петров Ал. А. Сесквитерпановые углеводороды нефтей. Нефтехимия 1976. Т. 16, С. 18-22. [Trash G.R., Pustylnikov S.D., Pehk T.I., Denisov V.Yu., Petrov Al.A. Seskviterpenovy hydrocarbon of oils. Petrochemicals 1976. Vol. 16, P. 18-22. (In Russ.)]

22. Воробьева Н.С., Земскова З.К., Петров Ал.А. Полициклические нафтены состава C14 - С26 в нефти месторождения Сива. Нефтехимия 1978. Т. 18, С. 855-863. [Vorobyeva N.S., Zemskova, Z.K., Petrov Al.A. Polycyclic naphthenes of composition C14 - C26 in oil field Siwa. Petrochemicals 1978. Vol. 18, P. 855-863. (In Russ.)]

23. Конторович А.Э., Каширцев В.А., Данилова В.П. и др. Молекулы-биомаркеры в ископаемом органическом веществе и нафтидах докембрийских и фанерозойских пород Сибиpu. Спб.: ВНИГРИ, 2009. 108 с. [Kontorovich A.E., Kashirtsev V.A., Danilova V.P. etc. Molecular biomarkers in fossil organic matter and naphthide Precambrian and Phanerozoic rocks of Siberia. Saint Petersburg: VNIGRI, 2009. 108 p. (In Russ.)]

24. Каширцев В.А., Конторович А.Э., Москвин В.И. и др. Терпаны нефтепроявлений озера Байкал. Нефтехимия 2006. Т. 46(4), С. 243-250. [Kashirtsev V.A., Kontorovich A.E., Moskvin V.I. 
and etc. Terpanes of oil seepage of the lake Baikal. Petrochemicals 2006. Vol. 46(4), P. 243-250. (In Russ.)]

25. Конторович А.Э., Каширцев В.А., Москвин В.И. и др. Нефтегазоносность отложений озера Байкал. Геология и геофизика 2007. T. 48(12), С. 1346-1356. [Kontorovich A.E., Kashirtsev V.A., Moskvin V.I., etc. The Petroleum potential of sediments of lake Baikal. Geology and Geophysics 2007. Vol. 48(12), P. 1346-1356. (In Russ.)]

26. Ву Ван Хай, Серебренникова О.В. Состав насыщенных углеводородов битумов Северной Хакасии. Известия Томского политехнического университета 2012. Т. 321(3) С. 161-165. [Wu Wang Khai, Serebrennikova O.V. The Composition of saturated hydrocarbons of the bitumen North of Khakassia Republic. Bulletin of the Tomsk Polytechnic University 2012. T. 321(3) P. 161-165. (In Russ.)]

27. Alexander R., Kagi R., Noble R. Identification of the bicyclic sesquiterpenes, drimane, and eudesmane in petroleum. Journal of the Chemical Society Chemical Communications 1983. Vol. 5, P. 226-228.

28. Chirkova D. Yu., Krasnoyarova N.A., Serebrennikova O.V. and Wu Wang Khai. Characteristic Features of the Hydrocarbon Composition of Paleozoic Oils from the Southeast of Western Siberia. Petroleum Chemistry 2014. Vol. 54(6), P. 397-405.

29. Volkman J.K. Biological marker compounds as indicators of the depositional environments of petroleum source roks. In: Lacustrine Petroleum Source Rocks (A.J. Fleet, K. Kelts, and M.R. Talbot, eds.). Geological Society Special Publication 1988. Vol. 40, P. 103-122.

30. Семенов А.А., Карцев В.Г. Основы химии природных соединений. М.: Издано Международным благотворительным фондом «Научное Партнерство», МБФНП, 2009. Т. 1, 619 с. [Semenov A.A., Kartsev, V.G. Foundations of the chemistry of natural compounds. Moscow: Published by the (International charitable foundation "Scientific Partnership Foundation", ICSPF), 2009. Vol. 1, 619 p. (In Russ.)]

31. Fazeelat T., Alexander R., Kagi R.I. Effect of Maturity on the Relative Abundances of 8,14-secohopanes in Sedimenta and Crude oils. Journal of Chemical Society of Pakistan 1999. Vol. 21(2), P. 154-163.

32. Петров Ал.А. Биометки и геохимические условия преобразования нефтей России. Геология нефти и газа 1994. Т. 6, С. 13-19. [Petrov Al.A. Biometry and geochemical conditions of the transformation of oil of Russia. Geology of oil and gas 1994. Vol. 6, P. 13-19. (In Russ.)]

33. Петров Ал.А. Геохимическая типизация нефтей. Геохимия 1994. Т. 6, С. 876-891. [Petrov Al.A. Geochemical typing of crude oils. Geochemistry 1994. Vol. 6, P. 876-891. (In Russ.)]

34. Петров Ал. Углеводороды нефти. М.: Наука, 1984. 264 с. [Petrov Al. The petroleum hydrocarbons. Moscow: Nauka, 1984. 264 p. (In Russ.)]

35. Иванова И.К. Моноалкилбензоль в нефтях венд-кембрийских отложений. М.: Нефтегазовое дело 2008. http:www.ogbus.ru [Ivanova I.K. monoalkylbenzenes in oils of the VendianCambrian deposits. Moscow: Oil and gas business 2008. (In Russ.)]

36. Blumer M., Mullin M.M., Guillard R.R. L. A polyunsaturated hydrocarbon (3-,6-,9-,12-,15-, 18-heneicosahexaene) in the marin food web. Mar. Biol. 1970. Vol. 6(3), P. 226-235. 
37. Ellis L., Singh R.K., Alexander R., Kagi R.I. Geosynthesis of organic compounds. Formation of alkyltoluenes and alkylxylenes in sediments. Geochimica et Cosmochimica Acta 1995. Vol. 59, P. $5133-5140$.

38. Albaiges J., Algaba J., Clavell E., Grimalt J. Petroleum geochemistry of theTarragona basin (spanish mediterranean off-shore). Organic Geochemistry 1986. Vol. 10, P. 441-450.

39. Sinninghe Damste J.S., Kock-van Dalen A.C., Albrecht P.A., de Leeuw J.W. Identification of long-chain 1,2-di-n-alkylbenzenes in Amposta crude oil from the Tarragona Basin, Spanish Mediterranean: implications for the origin and fate of n-alkylbenzenes. Geochimica et Cosmochimica Acta 1991. Vol. 55, P. 3677-3683.

40. Radke M. Organic Geochemistry of Aromatic Hydrocarbons. In Advances in Petroleum Organic Geochemistry (J. Brooks, and D.H. Welte, Eds.) 1987. Vol. 2, P. 141-217.

41. Radke M., Welte D.H. The methylphenantrene index (MPI) a maturity parameter based on aromatic hydrocarbons. In Advances in Organic Geochemistry. Under Ed. BjorØy M. et al. (Wiley and Sons, Chichester) 1981. P. 504-512. 